EGU21-11917, updated on 30 Jul 2021

https://doi.org/10.5194/egusphere-egu21-11917

EGU General Assembly 2021

(c) Author(s) 2021. This work is distributed under

the Creative Commons Attribution 4.0 License.

\title{
Potential impacts of warming climate on future water resources and hydropower production in a glacierized catchment in Western Himalaya
}

Tejal Shirsat ${ }^{1}$, Anil Kulkarni ${ }^{1}$, Andrea Momblanch ${ }^{2}$, Surjeet Singh Randhawa ${ }^{3}$, and Ian Holman ${ }^{2}$

${ }^{1}$ Indian Institute of Science, Bangalore, India

${ }^{2}$ Cranfield University, Bedfordshire, UK

${ }^{3}$ Himachal Pradesh Council for Science Technology and Environment, Shimla, India

The Himalayan region has a large hydropower potential due to the natural topographic gradient and abundance of water resource from rainfall, snow and glacier melt. However, future water availability in the Himalayan streams is likely to be altered due to climatic conditions, which necessitates an assessment of hydropower investments, especially for small run-of-the-river projects. Here, we study the future glacio-hydrological changes in a small catchment located in the Upper Beas basin, in Western Himalaya in India, and their impacts on the operation of two small hydropower projects with contrasting hydrological requirements. The Water Evaluation and Planning (WEAP) model is used to integrate and analyse changes in cryosphere, hydrology and hydropower production in the middle and end of the 21 st century using multiple climate models representing different types of future scenarios under RCP 4.5 and 8.5. In response to projected climate, the snow and glacier melt contribution to annual discharge declines from $34 \%$ in the baseline to $16.5 \%$ (RCP4.5) and 13.8\% (RCP8.5) by the end of the century. The total streamflow shows broad uncertainty in magnitude and direction of change but shows a noticeable seasonal shift in the hydrological cycle. Of the two hydropower projects, the plant that utilizes high flows with low hydraulic head shows a behaviour similar to streamflow projections resulting in $13 \%$ (RCP45) and 19.7\% (RCP85) increase in annual power generation by the end of the century arising from the increased hydropower potential of low flows and the rise in precipitation. The second power project that relies on lesser flows with high head maintains its designed power production consistently throughout the century in all the climate change scenarios. The differing sensitivity of the power projects to climate change is influenced by future changes in the runoff as well as by their design. Thus, this study provides insights into the climate-adaptive development and planning of small hydropower projects in the Himalayan region. 